\title{
Cultural Resource Investigation for the Materials and Fuels Complex Wastewater System Upgrade at the Idaho National Laboratory
}

Brenda R. Pace Dino Lowrey Hollie Gilbert Julie Braun Williams Julie Brizzee

May 2010

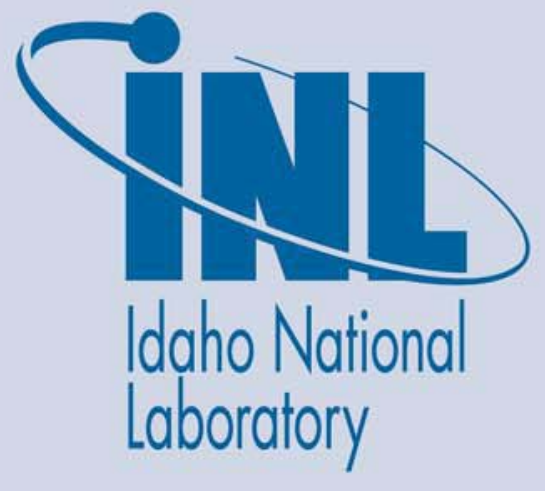

The INL is a U.S. Department of Energy National Laboratory operated by Battelle Energy Alliance 


\section{DISCLAIMER}

This information was prepared as an account of work sponsored by an agency of the U.S. Government. Neither the U.S. Government nor any agency thereof, nor any of their employees, makes any warranty, expressed or implied, or assumes any legal liability or responsibility for the accuracy, completeness, or usefulness, of any information, apparatus, product, or process disclosed, or represents that its use would not infringe privately owned rights. References herein to any specific commercial product, process, or service by trade name, trade mark, manufacturer, or otherwise, does not necessarily constitute or imply its endorsement, recommendation, or favoring by the U.S. Government or any agency thereof. The views and opinions of authors expressed herein do not necessarily state or reflect those of the U.S. Government or any agency thereof. 


\title{
Cultural Resource Investigation for the Materials and Fuels Complex Wastewater System Upgrade at the Idaho National Laboratory
}

\author{
Brenda R. Pace \\ Julie Braun Williams \\ Hollie Gilbert \\ Dino Lowrey \\ Julie Brizzee
}

May 2010

\begin{abstract}
Idaho National Laboratory
Cultural Resource Management

Idaho Falls, Idaho 83415
\end{abstract}

http://www.inl.gov

Prepared for the

U.S. Department of Energy

Assistant Secretary for Environmental Management

Under DOE Idaho Operations Office

Contract DE-AC07-05ID14517 


\begin{abstract}
The Materials and Fuels Complex (MFC) located in Bingham County at the Idaho National Laboratory (INL) in southeastern Idaho is considering several alternatives to upgrade wastewater systems to meet future needs at the facility. In April and May of 2010, the INL Cultural Resource Management Office conducted archival searches, archaeological field surveys, and coordination with the Shoshone-Bannock Tribes to identify cultural resources that may be adversely affected by the proposed construction and to provide recommendations to protect any resources listed or eligible for listing on the National Register of Historic Places. These investigations showed that one National Register-eligible archaeological site is located on the boundary of the area of potential effects for the wastewater upgrade. This report outlines protective measures to help ensure that this resource is not adversely affected by construction.
\end{abstract}




\section{ACKNOWLEDGMENTS}

These cultural resource investigations could not have been completed without the capable field assistance of Dino Lowrey, Hollie Gilbert, and Julie Braun-Williams. Caroline Smith from the Shoshone-Bannock Tribe's Heritage Tribal Office kindly provided input on tribal concerns in the project area. Cheryl Swank provided formatting assistance and the document is enhanced by artifact sketches created by Dino Lowrey and maps created by Julie Brizzee. 


\section{CONTENTS}

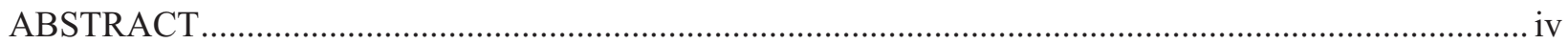

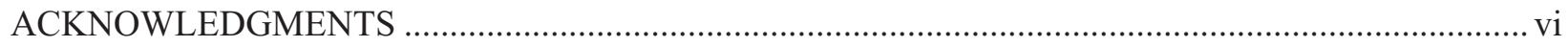

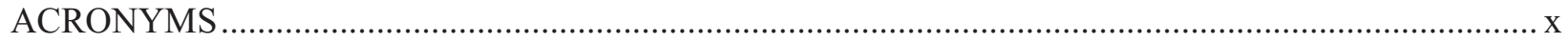

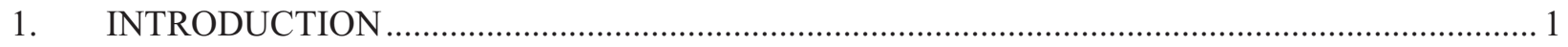

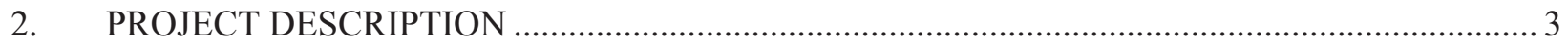

$2.1 \quad$ Area of Potential Effects ................................................................................................ 3

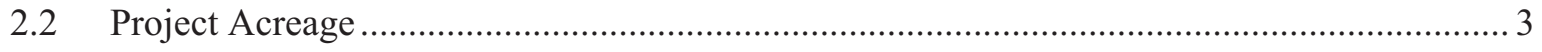

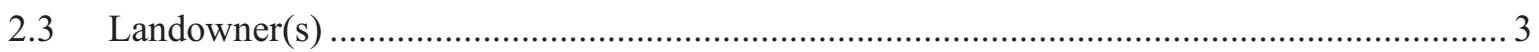

3. STATEMENT OF OBJECTIVES FOR INVESTIGATION ….................................................. 5

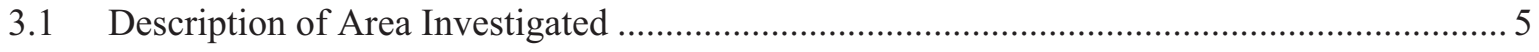

3.2 Amount and Types of Information Collected .................................................................. 5

4. LOCATION AND GENERAL ENVIRONMENTAL SETTING ............................................... 6

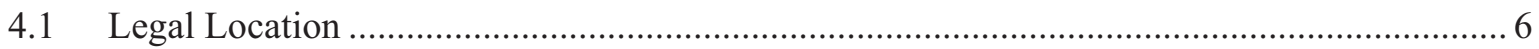

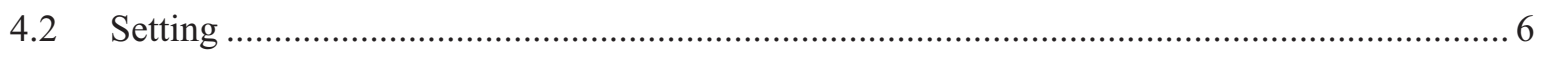

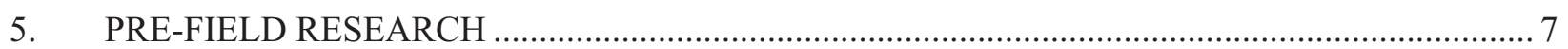

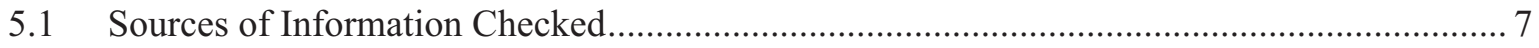

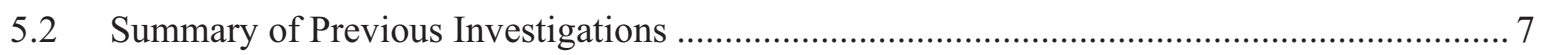

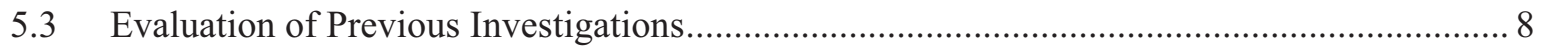

6. EXPECTED HISTORIC AND PREHISTORIC LAND USE AND SITE DENSITY ..................... 9

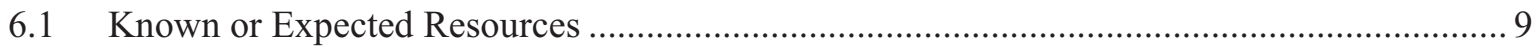

6.2 Known or Expected General Themes, Time Periods, and INL Contexts............................. 9

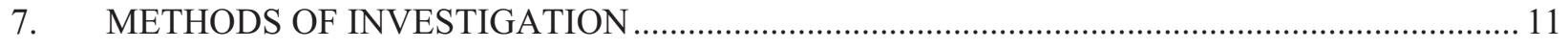

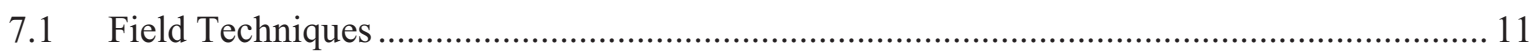

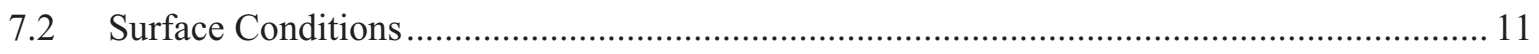

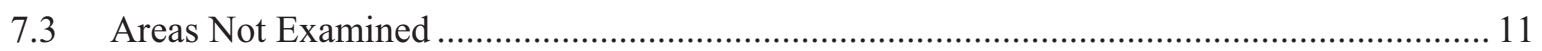

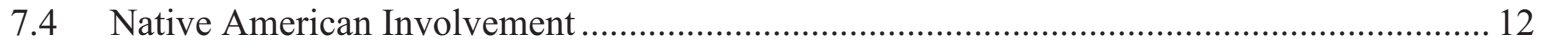

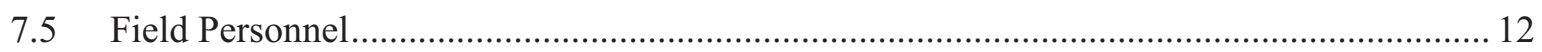

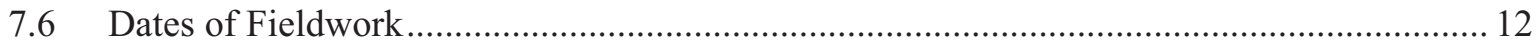

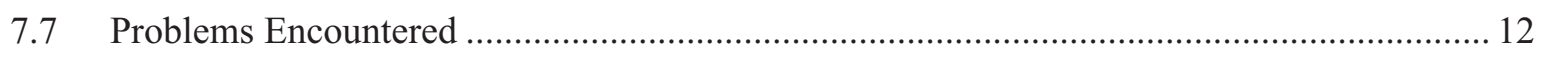

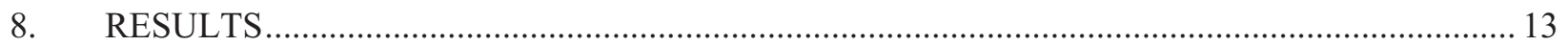

8.1 Resources Identified in the Area of Potential Effect......................................................... 13

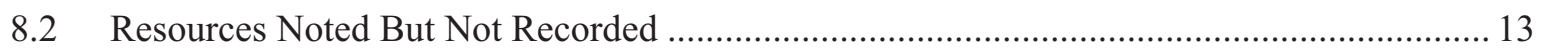

8.3 Summary of Important Characteristics of Identified Resources ........................................ 13

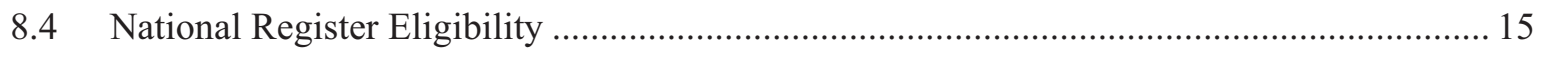




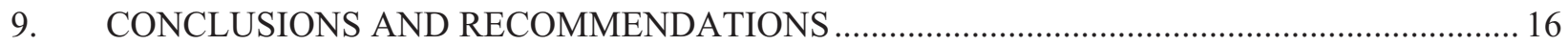

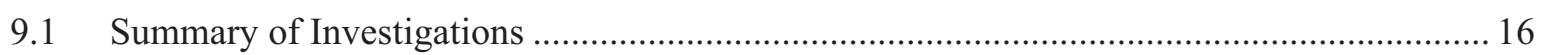

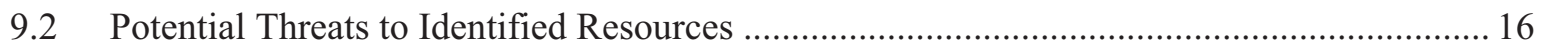

9.3 Relationship of Identified Resources to Project Impacts .................................................... 16

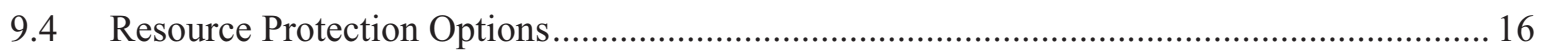

9.5 Recommendations for Additional Investigations or Protective Measures ........................... 17

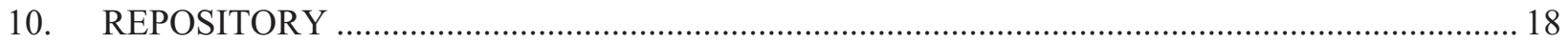

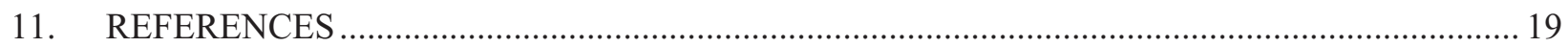

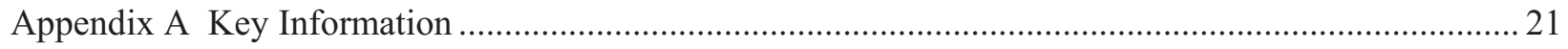

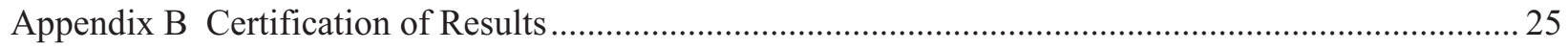

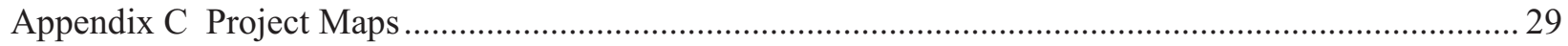

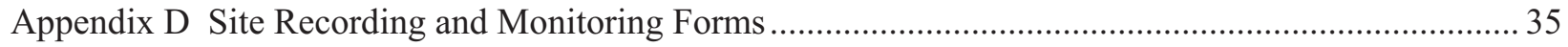

\section{FIGURES}

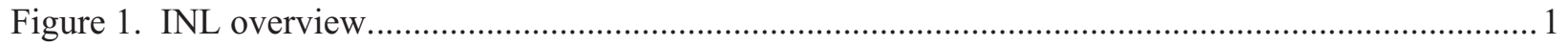

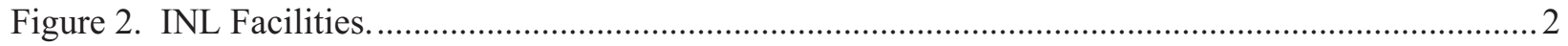

Figure 3. Area of potential effects for MFC wastewater system upgrade............................................... 4

Figure 4. Large notched point fragment from isolate location BEA-2010-16-01 ................................ 14

Figure 5. Elko Corner-Notched point fragment from 10BM247........................................................ 14

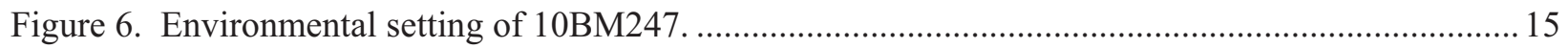

\section{TABLES}

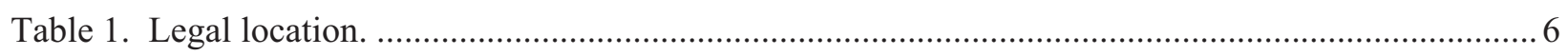

Table 2. General themes and time periods documented in the project area.......................................... 10

Table 3. INL-specific contexts documented in the project area............................................................ 10

Table 4. Archaeological resources identified in the MFC wastewater system upgrade area of

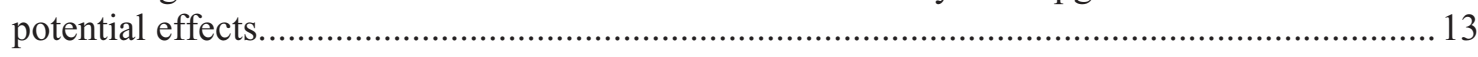




\section{ACRONYMS}

AIP Agreement in Principle

ANL-W Argonne National Laboratory-West

BEA Battelle Energy Alliance

BM Bingham (county)

BP before present (years)

CRM cultural resource management

DOE-ID Department of Energy-Idaho Operations Office

GIS geographical information systems

GPS global positioning system

INL Idaho National Laboratory

MFC Materials and Fuels Complex

NRHP National Register of Historic Places

SHPO State Historic Preservation Office

U.S. United States 


\section{Cultural Resource Investigation of the Materials and Fuels Complex Wastewater System Upgrade at the Idaho National Laboratory}

\section{INTRODUCTION}

The Idaho National Laboratory (INL) is an 890 square mile federal reserve covering portions of five counties on the northeastern edge of the Snake River Plain in southeastern Idaho (Figure 1). INL lands and facilities are under the jurisdiction of the U.S. Department of Energy, Idaho Operations Office (DOEID) and have been set aside since the 1940s to support science and engineering in nuclear energy and other disciplines (Stacy 2000). The Laboratory has also been designated a National Environmental Research Park, dedicated to the study of the environmental impacts of energy research (Irving 1993), and a portion of the land has been set aside as a Sagebrush Steppe Ecosystem Reserve. Cultural resources including historic and prehistoric archaeological sites, historic architectural properties, and areas of importance to the Shoshone-Bannock Tribes and others are numerous across the Laboratory and are managed in accordance with the DOE-ID's Cultural Resource Management (CRM) Plan (DOE-ID 2009).

Figure 1. INL overview. 
There are currently nine main operational facility areas at the desert laboratory and one research and education complex in Idaho Falls (Figure 2). The Materials and Fuels Complex (MFC), formerly known as Argonne National Laboratory-West (ANL-W), is the easternmost of INL's desert facilities. In anticipation of immediate and future growth, a significant upgrade is proposed for wastewater systems at MFC. This report documents archival research and field investigations to identify cultural resources located in the area of potential effects for construction activities related to the proposed wastewater system upgrade. Recommendations for future strategies to avoid any adverse impacts to identified cultural resources are also included. The document is presented in a specific format preferred by the Idaho State Historic Preservation Office (Idaho SHPO 1995) and required by the INL CRM Plan (DOEID 2009).

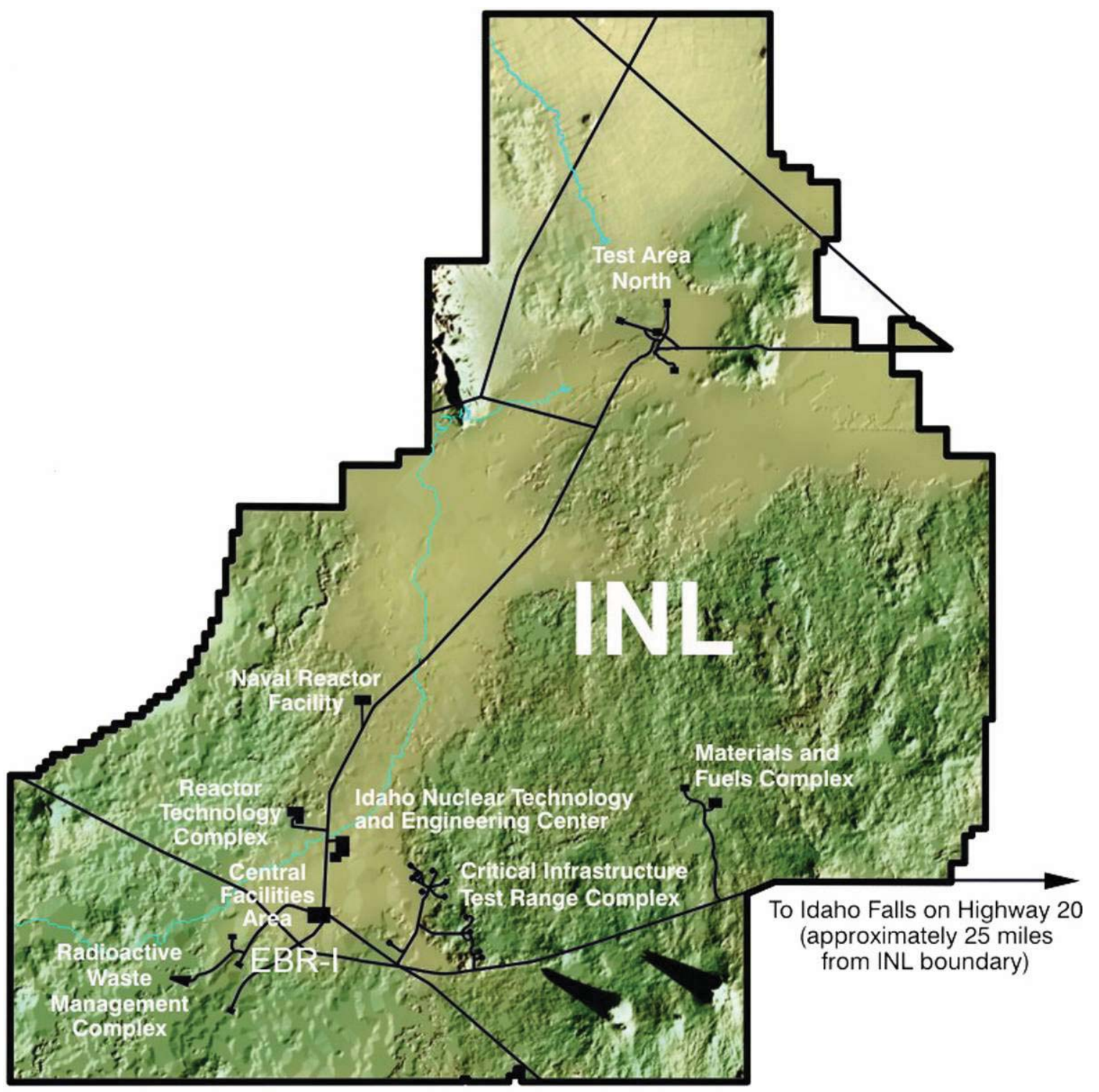

Figure 2. INL Facilities. 


\section{PROJECT DESCRIPTION}

Existing wastewater facilities at MFC are located immediately to the north of the fenced, developed facility campus. Several options are under consideration to expand the system including overflow holding tanks, up to four new lagoons, land application systems, and some options that include combinations of all of these basic elements. Changes to basic utility infrastructure (e.g. water lines, power, access roads, security buffers) will also be needed to support the project. All options under consideration would be located in a previously undeveloped area to the northeast of existing facilities (Figure 2).

\subsection{Area of Potential Effects}

The area of potential effects for the proposed wastewater system upgrade is a currently undeveloped 80-acre plot to the northeast of the fenced facility perimeter at the MFC (Figure 3). Existing wastewater lagoons lie to the west and the MFC Firing Range safety fan forms the northwestern boundary. All proposed activities associated with construction and operation of the new wastewater system are expected to be contained within this 80 -acre area. Ground disturbance is expected to be intensive, involving heavy equipment to reshape the land surface and build the chosen facilities. New roads, utilities, and security buffers may also be established within the 80 -acre area.

Archaeological resources and natural resources of importance to the Shoshone-Bannock Tribes located in the 80 -acre area could be subject to direct impact during construction of the wastewater facilities and associated infrastructure. Impacts will primarily result from heavy equipment operations. Once construction is completed and the new system is in operation, new direct impacts are unlikely. However, indirect impacts to cultural resources may result from an increase in overall activity in a previously undeveloped portion of the INL. Archaeological sites, wildlife, and plants may be impacted by increased traffic, introduction and spread of invasive/noxious weeds, casual visitation, and unauthorized artifact collection.

\subsection{Project Acreage}

All activities associated with the construction and operation of the proposed new MFC wastewater system upgrade will be located in an 80 -acre plot northeast of the existing facility perimeter fence.

\subsection{Landowner(s)}

Lands within the boundaries of INL are under the jurisdiction of the U.S. Department of Energy, Idaho Operations Office (DOE-ID) with the assistance of DOE-ID's prime operations contractor, Battelle Energy Alliance (BEA) and the Idaho Cleanup Project contractor, CH2M-WG Idaho, LLC (CWI). Lands within the Naval Reactors Facility are not administered by DOE-ID. Within INL grazing areas, administration is also shared with the Bureau of Land Management, Upper Snake River District, which issues and administers permits for these activities. The proposed MFC wastewater system upgrade is located on lands under the sole jurisdiction of DOE-ID. 


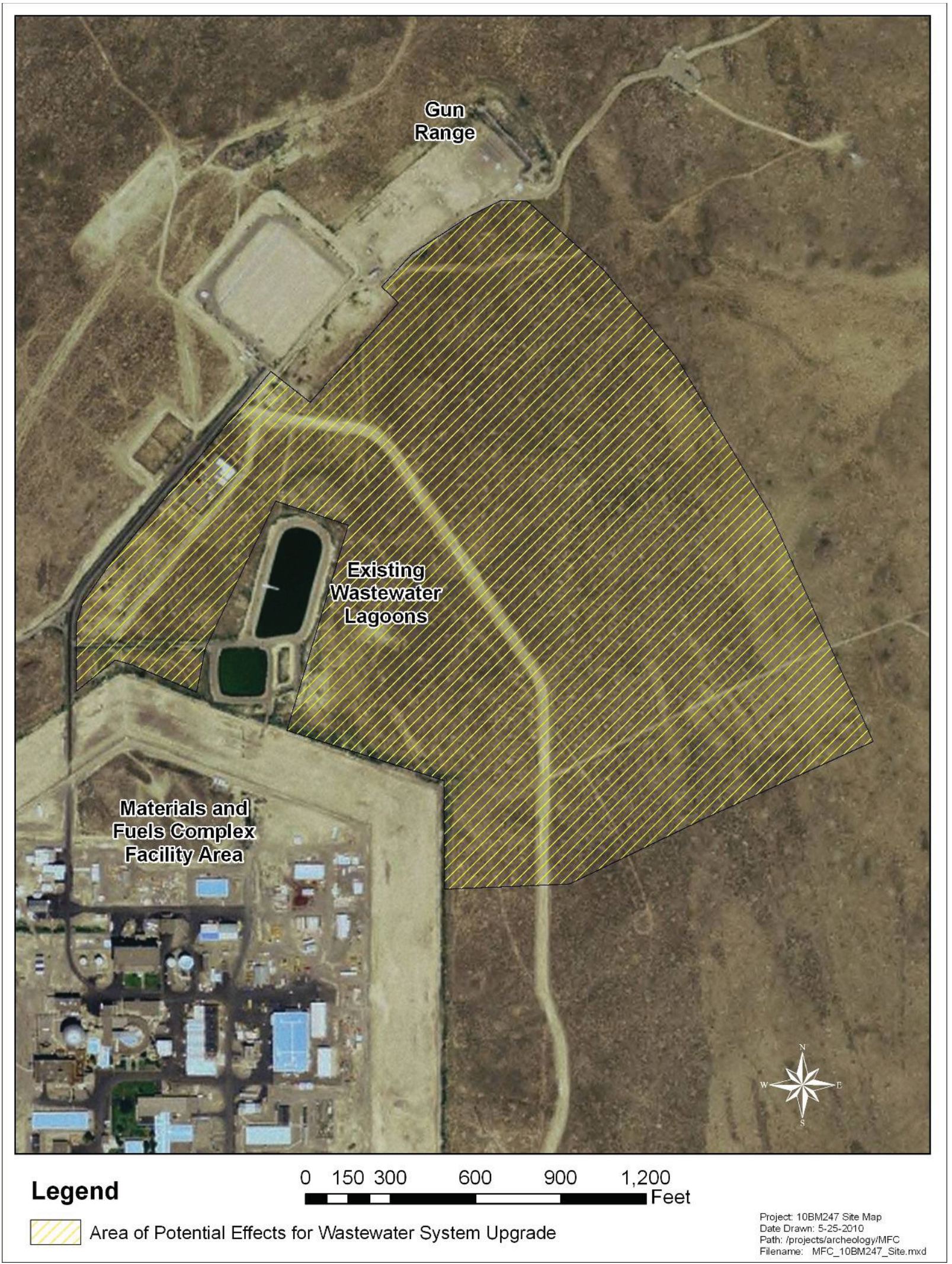

Figure 3. Area of potential effects for MFC wastewater system upgrade. 


\section{STATEMENT OF OBJECTIVES FOR INVESTIGATION}

The cultural resource investigations reported herein were conducted to satisfy three basic and interrelated goals:

- Identify cultural resources within the area of potential effects for the proposed MFC wastewater system upgrade

- Conduct a preliminary assessment of the potential effects of construction activities on any identified cultural resources, particularly those listed on or eligible for listing on the National Register of Historic Places

- Develop recommendations for strategies to ensure that effects to identified cultural resources are not adverse when construction plans are finalized

\subsection{Description of Area Investigated}

The MFC wastewater system upgrade is located in an 80-acre plot of undeveloped land adjacent to the current MFC facility perimeter fence. A number of cultural resource investigations have been conducted in the MFC area over the past three and a half decades. A summary of these previous investigations is provided in Section 5.0.

In 2010, to supplement earlier investigations and obtain a full assessment of potential impacts associated with the proposed wastewater system upgrades, field investigations were focused in the 80acre area of potential effects and at one previously recorded archaeological site located in this area.

\subsection{Amount and Types of Information Collected}

All cultural resources investigations completed at INL must meet the Secretary of the Interior's standards under 36 CFR Part 800, as well as the tailored requirements outlined in the INL CRM Plan (DOE-ID 2009). In general, ground disturbing projects at INL are preceded by several types of data collection including: cultural resource archive searches, archaeological reconnaissance surveys in previously examined areas, and/or intensive archaeological surveys in areas that have never been systematically inventoried for cultural resources. Representatives from the Shoshone-Bannock Tribes are involved in INL field surveys and are invited to assist in the identification and protection of resources of traditional cultural or religious importance. All of these activities are designed to identify cultural resources in the areas of potential effect for proposed activities.

Investigations conducted near MFC in 2010 were designed to ensure that all archaeological resources with visible surface remains were identified within the 80 -acre proposed wastewater system upgrade. In this context, areas that have not been intensively examined since 1988 were re-surveyed with intensive methods and the single known archaeological site within the 80 -acre area of potential effects was revisited and assessed. Once plans for the actual wastewater system upgrade are finalized, additional cultural resource coordination will be necessary to ensure that the effects of construction will not be adverse in this sensitive archaeological site area. Section 9.0 provides recommendations for the monitoring and coordination that will accomplish this protection. 


\section{LOCATION AND GENERAL ENVIRONMENTAL SETTING}

The proposed MFC wastewater system upgrade is located in the eastern portion of the Laboratory, a few miles north of U.S. Highway 20. Figures 2 and 3 illustrate the location. A companion set of maps included in Appendix C depict archaeological resources identified in the area of potential effects.

\subsection{Legal Location}

Table 1. Legal location.

\begin{tabular}{|c|l|}
\hline $\begin{array}{c}\text { AREA OF POTENTIAL } \\
\text { EFFECTS }\end{array}$ & \multicolumn{1}{|c|}{ LEGAL LOCATION } \\
\hline $\begin{array}{c}\text { MFC wastewater system upgrade } \\
(80 \text { acres })\end{array}$ & $\begin{array}{l}\text { Southern } 1 / 2 \text { Section } 12 \text { and northern } 1 / 4 \text { Section } 13, \mathrm{~T} 3 \mathrm{~N}, \mathrm{R} 32 \mathrm{E}, \\
\text { Bingham County }\end{array}$ \\
\hline
\end{tabular}

\subsection{Setting}

The INL is located in the high cool desert environment of the northeastern Snake River Plain. Within the 890 square mile Laboratory complex, aeolian, alluvial, and lacustrine sediments of varying thicknesses overlie basaltic lava flows. The Big Lost River flows in a northeasterly direction from the southwestern corner of the Laboratory to eventually terminate in a series of natural sinks near the foothills of the Lemhi Mountains. An extensive floodplain follows the course of the River and in the vicinity of the sinks, a myriad of channels is cut into the now-dry bed of Pleistocene Lake Terreton. Vegetation is generally sparse and dominated by a community of low shrubs like sage and rabbitbrush, a wide variety of grasses and forbs, and occasional juniper trees. Many animals make their homes in this sagebrush grassland including pronghorn, deer, elk, coyotes, badgers, rabbits, many birds including raptors, game birds, and waterfowl, a wide variety of small rodents, and several types of small reptile.

For human populations, the area has always had much to offer. For Native American huntergatherers who probably utilized the area on a seasonal basis for more than 12,000 years, game animals and useful plants were found in abundance and nearby Big Southern Butte was attractive for the obsidian toolstone that outcrops near it's crest. Within the last 150 years, emigrants began to pass through the area along a northern spur of the Oregon Trail (Goodale's Cutoff). Soon thereafter, early homesteaders sought to harness the fickle flows of the Big Lost River and transform sagebrush flats into green pastures. Few were successful, but the failure of their efforts opened the area for use of another kind. The remote and largely uninhabited expanse of the northeastern Snake River Plain was well suited for the test firing of large guns and ordnance testing in support of U.S. military applications. After this initial period of military use, the INL was designated as the National Reactor Testing Station and became an ideal testing ground for the developing U.S. nuclear research program after 1949. The Laboratory has filled a similar role for more than 50 years, ultimately influencing nearly every power reactor in the world particularly in regard to design and safety (Stacey 2000).

The proposed MFC wastewater system upgrade is located in an undeveloped area dominated by lowrelief volcanic landforms. Basaltic pressure ridges, intermittent drainage channels, and small, closed basins add slight variation to the generally flat terrain. Exposures of basalt bedrock are common along ridge tops and aeolian sands have accumulated on the lee sides of some of these ridges, particularly where range fires have burned. Elevations average 5,120 ft. Plant life is typical of INL as a whole, dominated by low shrubs (sagebrush, rabbitbrush), various grasses, and forbs. 


\section{PRE-FIELD RESEARCH}

The INL CRM Office maintains an active archive of cultural resource investigations conducted at INL. This includes a wide variety of supporting documentation as well as the following specific records:

- Reports of reconnaissance-level archaeological surveys completed before 1984

- Reports of intensive archaeological surveys completed after 1984, including site forms

- Reports of archaeological test excavations conducted on INL lands, including field notes

- Archaeological sensitivity maps with predicted resource densities (Ringe 1995, Holmer et al. 2002)

- $\quad$ Maps and survey notes from government-sponsored land surveys of INL lands, ca 1884-1949

- Historic aerial photos of INL lands taken in 1949

- Reports of architectural surveys of all DOE-ID owned INL buildings (Arrowrock 1997)

- Historic and current plot plans of INL buildings and facility areas

- Microsoft Access and geographical information systems (GIS) maps and databases with information specific to the archaeological sites and historic architectural properties identified at INL.

All archaeological investigations completed at INL are preceded by checks of these archival materials to determine the nature and extent of previous research in a given area.

\subsection{Sources of Information Checked}

Several sources of information were consulted prior to 2010 field work in the MFC wastewater system upgrade project area, including the following specific records:

- INL CRM project files

- INL CRM archaeological site databases and GIS maps

- Archaeological survey reports

- Historic aerial photographs of the project area taken in 1949

\subsection{Summary of Previous Investigations}

Archaeological investigation of the MFC (then ANL-W) area began in 1975 with completion of a series of small surveys to support facility developments through approximately 1984 (e.g. small facilities, fiber optic lines, security roads, etc.) A full listing of these projects is found in the INL CRM Plan, Appendix J (DOE-ID 2009:409-448). During one of these surveys, several archaeological sites were identified but not fully documented around the perimeter of the ANL-W Firing Range Safety Fan, which is located along the northwestern edge of the 80 -acre area of potential effects for the new wastewater system upgrade.

In 1988, approximately 700 acres surrounding MFC, which were designated as the ANL-W administrative boundary at that time, were surveyed for archaeological resources (Ringe and Holmer 1988). This survey resulted in the recording of twelve archaeological sites and 22 isolated artifact locations. Subsequent consultation with the Idaho State Historic Preservation Office confirmed that the twelve identified sites are potentially eligible for nomination to the National Register of Historic Places and that the isolates are not eligible. Avoidance was the preferred management option at the time for all of the National Register-eligible archaeological sites and no further work was recommended for isolates.

INL CRM archives indicated that the entire 80 -acre area of potential effects for wastewater system upgrades was included in the 1988 survey and that one of the National Register-eligible archaeological 
sites identified then is located in the northern-most portion of the 80 -acre project area. Additional details on this site are included in Sections 8.0 and 9.0 and Appendices C and D of this report.

\subsection{Evaluation of Previous Investigations}

Since 1984, archaeological surveys of INL lands have been intensive and conducted according to the standards currently outlined in the INL CRM Plan (DOE-ID 2009). Prior to this time, INL archaeological surveys were not necessarily intensive and documentation may not meet current standards. The 1988 survey of the ANL-W Administrative Boundary was intensive. However under the INL CRM Plan in use in 2010, areas that were intensively surveyed more than ten years ago are subject to new archaeological reconnaissance when new ground-disturbing projects are proposed there. INL CRM policies for reexamination of previously surveyed areas help to ensure that any area proposed for new ground disturbance is intensively examined (transect interval $\leq 20 \mathrm{~m}$ ) and that all cultural resources with visible surface remains are documented. The 2010 fieldwork conducted in the area of potential effects for the MFC wastewater system upgrade confirms the validity and intensity of the original surveys and indicates that all National Register-eligible resources that exist in the project area have been identified. 


\section{EXPECTED HISTORIC AND PREHISTORIC LAND USE AND SITE DENSITY}

Previous archaeological investigations in the vicinity of MFC (cf. Ringe and Holmer 1988) provide a solid basis for anticipating the nature and extent of archaeological resources in and around the project area. Indeed, repeated surveys and revisits to the archaeological site known to occur there provide a complete inventory of the archaeological sites present in the area of potential effects for the current project. In addition, these investigations provide a unique record of the dynamic nature of surface soils in this area.

Although none of the archaeological sites originally recorded during intensive survey of the ANL-W Administrative Boundary in 1988 appear to have been completely covered by loose surface soils and no new archaeological sites have been revealed through deflation, the character of the exposed surfaces do appear to have changed over the past two decades. Direct comparison of chipped stone tool artifact distributions is complicated because 1988 survey protocols involved nearly complete collection and subsequent curation of nearly all stone tools encountered. However, 1988 descriptions of the density and distributions of stone tool manufacturing debris and nondiagnostic artifacts that were not collected do often differ slightly from 2010 observations. These slight differences are due to the ongoing effects of fire, wind, snow melt, desiccation and cracking, and animal movement. They suggest that buried artifacts and features may be present within the boundaries of previously recorded resources, even if there are few artifacts currently exposed at the surface.

\subsection{Known or Expected Resources}

The inventory of known previously recorded cultural resources in the vicinity of MFC includes short term hunting camps, lithic scatters, and isolated artifact locations from the prehistoric period $(12,000-$ 150 years before present $[\mathrm{BP}])$. Although not formally documented at this time, other resources that are of traditional, cultural, and sacred importance to local tribal people from the Shoshone-Bannock Tribes may also be located in the area. Archaeological resources dating to historic times $(50-150 \mathrm{BP})$ have also occasionally been found in the area. The known historic archaeological inventory includes trash scatters, historic trails, and isolated artifact locations.

Only one previously recorded prehistoric archaeological site, designated as 10BM247, was confirmed to be located in the area of potential effects for wastewater system upgrades. In 1988, this small site was evaluated as follows:

"10BM247: Undisturbed short term campsite which probably contains a buried cultural feature. Datable materials may be contained in this feature in addition to diagnostic artifacts which could help establish the function of this site. This data could be used to address research questions concerning prehistoric hunting practices. Avoidance is recommended to preserve these buried deposits for future research.” (Ringe and Holmer 1988:144)

\subsection{Known or Expected General Themes, Time Periods, and INL Contexts}

The following Tables illustrate the general themes, time periods, and INL-specific contexts documented within the archaeological record of the MFC area. 
Table 2. General themes and time periods documented in the project area.

\begin{tabular}{|c|c|c|}
\hline \multicolumn{2}{|c|}{ THEMES } & TIME PERIODS \\
\hline$[\mathrm{x}]$ Archaeology & [ ] Military & {$[\mathrm{x}]$ Prehistoric } \\
\hline [x] Agriculture & [ ] Mining & {$[\mathrm{x}]$ Historic Native American } \\
\hline [ ] Architecture & [x] Native Americans & [x] Exploration: $1805-1860$ \\
\hline [ ] Civilian Conservation Corps & [ ] Politics/Government. & [x] Settlement: $1855-1890$ \\
\hline$[\mathrm{x}]$ Commerce & [x] Public Land Management & [x] Statehood: 1890-1904 \\
\hline [ ] Communication & [ ] Recreation/Tourism & [x] Statehood: 1904-1920 \\
\hline [ ] Culture and Society & {$[\mathrm{x}]$ Settlement } & [x] Interwar: 1920-1940 \\
\hline [ ] Ethnic heritage & [ ] Timber & [ ] Pre-Modern: 1940-1958 \\
\hline [ ] Exploration/Fur Trade & {$[\mathrm{x}]$ Transportation } & [ ] Modern: 1958-present \\
\hline [ ] Industry & [ ] Other & \\
\hline
\end{tabular}

Table 3. INL-specific contexts documented in the project area.

\begin{tabular}{|c|c|c|}
\hline $\begin{array}{l}{[\mathrm{x}] \text { Prehistoric Native }} \\
\text { American: } 15,000-150 \mathrm{BP}\end{array}$ & $\begin{array}{l}\text { [ ] Ordnance Testing, Naval } \\
\text { Proving Ground: } 1942-1949\end{array}$ & $\begin{array}{l}\text { [ ] Nuclear Reactor Testing, } \\
\text { Development: } 1955-1970\end{array}$ \\
\hline $\begin{array}{l}{[\mathrm{x}] \text { Historic Native American: }} \\
150 \mathrm{BP} \text { - present }\end{array}$ & $\begin{array}{l}\text { [ ] Ordnance Testing, Vietnam } \\
\text { War: } 1968-1970\end{array}$ & $\begin{array}{l}\text { [ ] Post Nuclear Reactor Research: } \\
1971 \text { - present }\end{array}$ \\
\hline $\begin{array}{l}\text { [x] Euro American Contact/ } \\
\text { Settlement: } 1805-1942\end{array}$ & $\begin{array}{l}\text { [ ] Nuclear Reactor Testing, } \\
\text { Establishment: } 1949-1971\end{array}$ & $\begin{array}{l}\text { [ ] Remediation of Nuclear Waste: } \\
1971 \text { - present }\end{array}$ \\
\hline
\end{tabular}




\section{METHODS OF INVESTIGATION}

All work during the 2010 cultural resource investigations of the MFC wastewater system upgrade was performed in a manner consistent with formal and informal standards and guidelines issued by the Idaho SHPO, the Advisory Council on Historic Preservation, the National Park Service, and Department of Interior, as outlined in DOE-ID's CRM Plan (DOE-ID 2009).

\subsection{Field Techniques}

The field survey tactics employed during the project were designed to provide intensive visual coverage of the current ground surface to ensure that all archaeological resources with visible surface remains were identified in the 80 -acre area of potential effects. Existing intensive survey results were utilized to the greatest extent possible. In addition to the new intensive surveys, the single previously recorded archaeological site documented in the 80-acre project area was revisited, its location was updated with global positioning system (GPS) technology, and its condition was assessed.

Intensive surveys at INL are accomplished through the use of systematic pedestrian transects with surveyors walking no more than 20 meters apart, typically in skirmish line fashion. In 2010, in the 80acre MFC wastewater system upgrade project area, transects were oriented according to existing roads and the MFC perimeter fence. A hand-held GPS unit with sub-meter accuracy was used to navigate to a previously recorded site, adjust the recorded location as needed, and to pinpoint the locations of a newly identified isolate location. Fieldwork in all areas was facilitated by trouble-free access on existing roads.

In general, when cultural materials are encountered during an intensive survey transect, previous survey records, including site forms, are consulted to determine if the newly discovered artifacts are associated with a known site or isolate location. At all newly discovered artifacts, careful searches $(3-5$ meter survey intervals) are conducted to ascertain the current boundaries of the resource and to pinpoint temporally or functionally diagnostic artifacts, artifact concentrations, cultural features, or areas of postdepositional disturbance. If the newly discovered artifacts fall within or near the original boundaries of a previously recorded site or isolate, monitoring forms are completed to document the location and current condition of the resource and note any new discoveries. When single unmodified flakes are identified in areas where no previously recorded resources were present, notations are made on field maps and notes, but no formal site recording forms are prepared. Occurrences of $2-9$ flakes or $1-9$ diagnostic artifacts in areas where no previously recorded resources were present are classified as "isolates" and are formally recorded. Formal recording is also completed for "sites" ( $\geq$ ten items within 100 meters or any number of items within an active geologic setting).

Only one isolated artifact was newly discovered during the 2010 survey of the 80 -acre MFC wastewater system upgrade project area and it was formally recorded by completion of an INL-tailored site recording form. Another INL-tailored site monitoring form was used to document the current condition of the single previously recorded site located in the area of potential effects for the project, 10BM247. Both recording and monitoring forms are included as Appendix D of this report. In all cases, newly found diagnostic artifacts were photographed and their relative positions recorded with the GPS unit. No artifacts were collected for permanent curation during the 2010 surveys.

\subsection{Surface Conditions}

Sparse vegetation at INL typically provides excellent surface visibility. In the MFC area, approximately $80 \%$ of the ground was un-obscured. Sunny conditions prevailed for most of the days spent in the field.

\subsection{Areas Not Examined}

The entire 80-acre area of potential effects for construction and operation of the MFC wastewater system upgrade and associated infrastructure were intensively surveyed in 2010. 


\subsection{Native American Involvement}

INL complies with and follows federal and state laws and regulations, DOE policies, and INLspecific management plans that define how DOE and its contractors will interact with Native Americans. More specifically, DOE-ID recognizes its trust responsibility to the Shoshone-Bannock Tribes, whose aboriginal lands include the INL. In the spirit of that responsibility, DOE-ID has entered into an Agreement in Principle (AIP) with the Tribes (DOE-ID 2007). In addition to defining a broad range of interests and working relationships, the AIP devotes particular attention to the management of INL

cultural resources. Broadly, its intent is to foster confidence on the part of the Shoshone-Bannock Tribes that INL cultural resources are managed in a spirit of protection and stewardship. To achieve this, the AIP provides for routine tribal participation in new and ongoing INL projects with an open invitation to comment on, visit, observe, and/or assist in cultural resource management investigations.

In 2010, representatives from the Shoshone-Bannock Tribe's Heritage Tribal Office were taken on a tour of the 80-acre MFC wastewater system upgrade project area and information was presented on the project at a regularly scheduled meeting of the Cultural Resource Working Group in May. Specific concerns about avoidance of site 10BM247 and monitoring of any construction activities conducted in proximity to it were expressed along with more general concerns about disturbances to plants and animals.

\subsection{Field Personnel}

All field work during the 2010 investigation was conducted by INL CRM Office personnel: Brenda R. Pace, Dino Lowrey, Hollie Gilbert, and Julie Braun Williams. Carolyn Smith and Anthony Bagley from the Shoshone-Bannock Tribes participated in the tribal tour.

\subsection{Dates of Fieldwork}

Fieldwork was conducted in April and May of 2010.

\subsection{Problems Encountered}

No problems were encountered. 


\section{RESULTS}

In 2010, the entire 80-acre area of potential effects for MFC wastewater system upgrades was intensively re-surveyed for cultural resources because the original 1988 survey was conducted more than two decades ago. The 2010 fieldwork confirmed the presence of one previously recorded prehistoric archaeological site on the northern boundary of the 80-acre area (10BM247). One previously unknown isolated prehistoric artifact was also identified in the northern portion of the 80-acre area (BEA-2010-1601). Specific Native American cultural resources have not been officially documented by the ShoshoneBannock Tribes in the area of potential effects for the MFC wastewater system upgrade. However, tribal representatives from the Shoshone-Bannock Tribe's Heritage Tribal Office toured the project area and expressed concerns with regard to protection of the previously recorded prehistoric archaeological site in the area (10BM247) as well as elements of the natural environment (plants, animals).

Additional information on the resources confirmed to be inside the 80 -acre area of potential effects is provided in the Sections to follow. INL CRM site recording and monitoring forms with detailed documentation of the new isolates and updated information on the previously recorded sites are provided in Appendix D and all of the resources are plotted on maps provided in Appendix C. Legal restrictions on the distribution of information detailing the exact location of archaeological sites may result in the removal of these Appendices from some versions of this report.

\subsection{Resources Identified in the Area of Potential Effect}

Field investigations in 2010 have confirmed that two prehistoric archaeological resources are present in the 80-acre area of potential effects for the MFC wastewater system upgrade. This includes one previously recorded prehistoric archaeological campsite and one newly recorded prehistoric isolate location (Table 4).

Table 4. Archaeological resources identified in the MFC wastewater system upgrade area of potential effects.

\begin{tabular}{|l|l|l|l|}
\hline \multicolumn{1}{|c|}{ SITE NO. } & DESCRIPTION & $\begin{array}{c}\text { RELATIONSHIP } \\
\text { TO PROJECT }\end{array}$ & \multicolumn{1}{|c|}{ 2010 OBSERVATIONS } \\
\hline 10BM247 & $\begin{array}{l}\text { Prehistoric } \\
\text { Campsite }\end{array}$ & northern boundary & $\begin{array}{l}\text { Light scatter of flakes and fire-cracked } \\
\text { rock as noted in 1988. New discovery } \\
\text { of a fragmentary dart point (Middle } \\
\text { Prehistoric 3,500 - 1,300 years BP) }\end{array}$ \\
\hline BEA-2010-16-01 & $\begin{array}{l}\text { Prehistoric } \\
\text { Isolate }\end{array}$ & $\begin{array}{l}\text { Fragmentary nondiagnostic dart point } \\
\text { fragment (General Middle Prehistoric } \\
7,500-3,500 \text { years BP) }\end{array}$ \\
\hline
\end{tabular}

\subsection{Resources Noted But Not Recorded}

All archaeological materials observed within the area of potential effects for the MFC wastewater system upgrade were either formally recorded or were incorporated into existing records for previously recorded resources. Based on tribal involvement in the 2010 fieldwork, it is likely that contemporary Native American cultural resource values are also located in the project area, but the Shoshone-Bannock Tribes have not pinpointed these resources at this time.

\subsection{Summary of Important Characteristics of Identified Resources}

Both of the archaeological resources identified within the area of potential effects for the MFC wastewater system upgrade contribute to the overall base of knowledge of prehistoric human use of the northeastern Snake River Plain. The isolated artifact location included in the inventory (BEA-2010-16- 
01) consists of a fragmentary dart point representative of the Middle Prehistoric period $(7,500-1,300$ BP) (Figure 4). Finds like this are quite common in the MFC area and across the lava plains of the INL. They represent short-term activity and are unlikely to yield any information beyond that which was collected during the initial formal field recording.

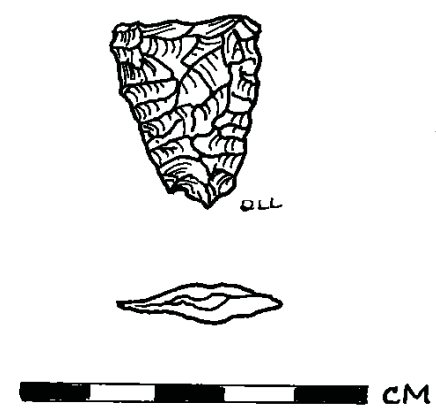

Figure 4. Large notched point fragment from isolate location BEA-2010-16-01.

In contrast, the prehistoric archaeological site (10BM247) identified in the area of potential effects for the MFC wastewater system upgrade does exhibit potential to yield additional information. This resource is characterized by a light scatter of stone flakes created during the maintenance and/or manufacture of stone tools. A fragmentary Elko Corner-Notched projectile point fragment suggests this activity may have occurred during the Middle Prehistoric III period (3,500 - 1,300 BP) (Figure 5). Partially buried pieces of fire-cracked river rock associated with these chipped stone artifacts are indicative of more intensive camping and resource processing and they may indicate the presence of a subsurface fire hearth or cooking feature. Cultural features like this are important because they could yield radiocarbon dates to help to delineate the temporal range of Elko style dart points in the region. Although the northern end of the artifact scatter has been impacted by grading along the MFC gun range boundary, the main concentration of artifacts retains good integrity and probably contains intact buried cultural deposits (Figure 6).

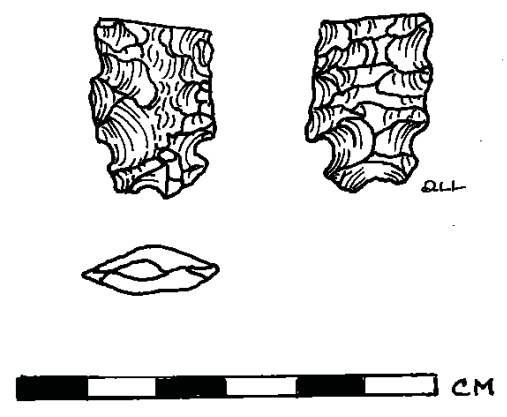

Figure 5. Elko Corner-Notched point fragment from 10BM247. 


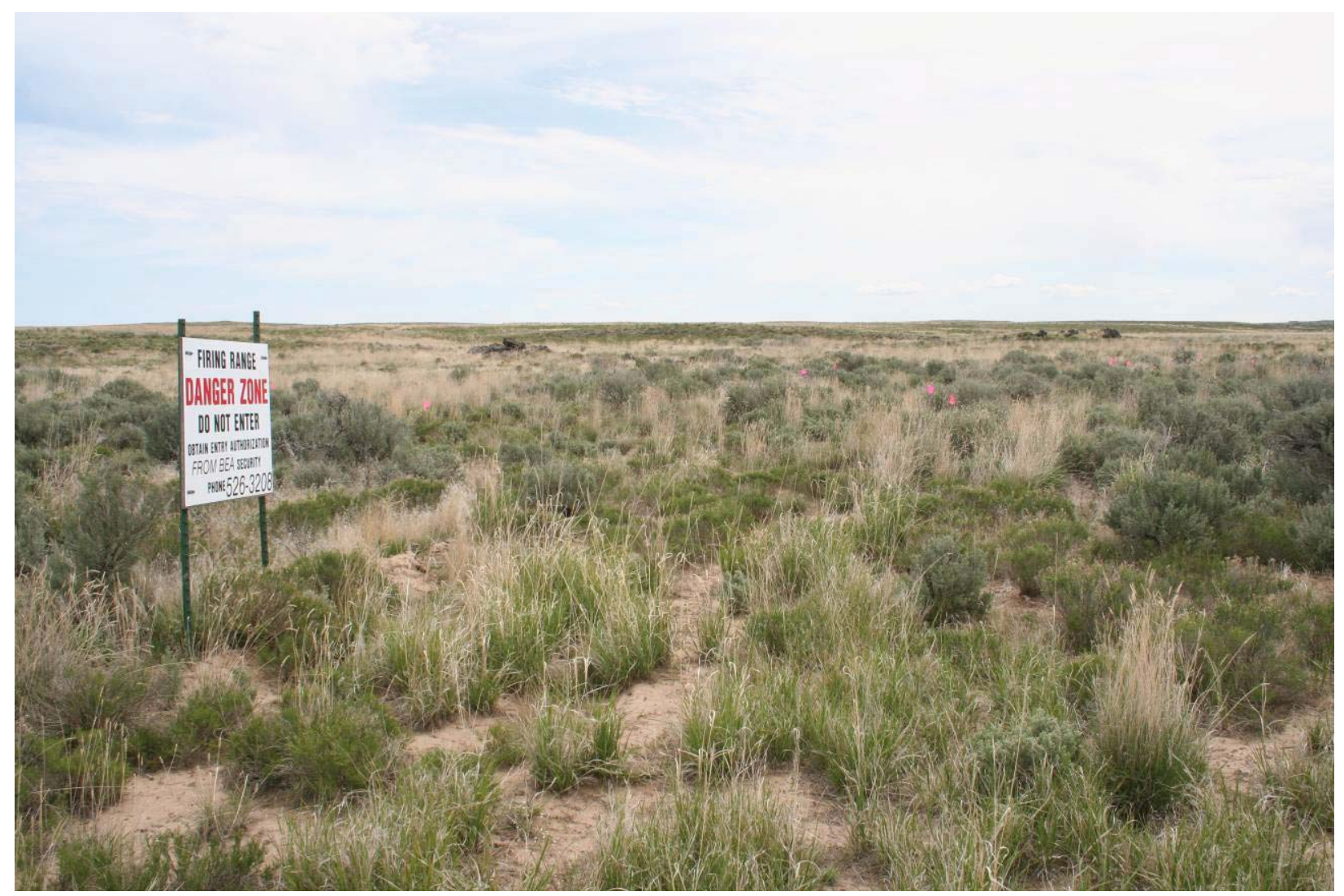

Figure 6. Environmental setting of 10BM247.

Specific Native American cultural resources within the area of potential effect and values associated with natural resources in the area have not been pinpointed. However, communication with tribal representatives has confirmed general concerns centered on protection of the identified archaeological site (10BM247), as well as natural resources in the area, which continue to fill important roles in tribal heritage and ongoing cultural traditions.

\subsection{National Register Eligibility}

The newly discovered isolated artifact location (BEA-2010-16-01) recorded in the northern portion of the area of potential effects for the MFC wastewater system upgrade is unlikely to yield any additional information important in the study of prehistory and is therefore considered to be ineligible for nomination to the National Register of Historic Places.

The previously recorded prehistoric campsite (10BM247) located on the northern boundary of the 80acre area of potential effects for the MFC wastewater system upgrade is considered to be potentially eligible for nomination to the National Register under criterion "d" of 36 CFR Part 60. The significance of this site is measured by its research potential. In this context, it is suspected of containing important subsurface cultural deposits accessible only through systematic archaeological excavation and intensive surface survey. Because these deposits are fragile and shallowly buried, equipment movement, vehicle traffic, and even heavy pedestrian traffic can easily disturb them. Precautionary measures must be implemented to ensure that the deposits at this site are not adversely impacted by activities associated with the MFC wastewater system upgrade. 


\section{CONCLUSIONS AND RECOMMENDATIONS}

The discussion to follow provides a synthesis of identified resources, potential impacts, and recommendations for avoiding adverse impacts during the proposed MFC wastewater system upgrade.

\subsection{Summary of Investigations}

Archaeological investigations completed in 2010 to assess the potential impacts of the MFC wastewater upgrade included cultural resource archive searches, intensive archaeological field surveys, and communication with Shoshone-Bannock tribal representatives. As a result of these activities, two archaeological resources were identified in the area of potential effects for the project. One resource is a newly discovered isolated artifact (BEA-2010-16-01), which provides important information on broad patterns of prehistoric human use of the region. However, it is unlikely to yield any additional information and is consequently evaluated as ineligible for nomination to the National Register of Historic Places. The second resource identified in the project area is a prehistoric archaeological campsite originally recorded in 1988 (10BM247). This resource exhibits potential for additional buried cultural deposits and is considered eligible for the National Register based on its potential to yield additional information important in the study of INL prehistory. Representatives from the Shoshone-Bannock Tribes have also indicated that this resource is of importance in tribal history and culture and have also indicated that native plants and animals in the area are of tribal importance.

\subsection{Potential Threats to Identified Resources}

Ground disturbance associated with the construction of new wastewater treatment facilities and associated infrastructure (i.e. utilities, access roads, security buffers) will be intensive and has the potential to impact any archaeological sites and natural resources of importance to the Shoshone-Bannock Tribes in the chosen footprint of the project. In addition to direct impacts from heavy equipment and earth-moving, archaeological sites and Native American resources identified in the area could also be subject to indirect impacts during construction as a result of higher visibility on the landscape and overall increases in activity levels in a previously undeveloped area. Artifacts may be subject to unauthorized collection or impacted by unauthorized off-road vehicle use. Resident and migratory birds and animals may be disturbed and noxious and invasive weeds may increase.

\subsection{Relationship of Identified Resources to Project Impacts}

Both of the identified archaeological resources are located in the northern portion of the 80-acre area of potential effects for the MFC wastewater system upgrade and the sensitive archaeological site actually sits along the northern boundary. However, plans for final placement of new facilities and infrastructure within this large area have not been finalized at this time.

\subsection{Resource Protection Options}

After plans are finalized with specific details on ground disturbing activities, it will be necessary to develop strategies to protect the identified resources. Protection can take several different basic forms in this context.

For the isolate location (BEA-2010-16-01), no further work is recommended unless project activities will result in direct impacts. In this case, the sensitive artifact should be relocated to an area that will be safe from ground disturbance. This intentional change to the original spatial distribution of this artifact will be carefully documented and made part of the permanent site records for this resource.

For the National Register-eligible prehistoric campsite (10BM247) located on the northern boundary of the project area, care must be taken to prevent any ground disturbance of the cultural deposits. This may require some modification of project plans to avoid the sensitive resource area. Semi-permanent 
markers may be necessary to delineate the area to be avoided. Depending on the nature and proximity of new facilities or utilities, a 30 - 50 meter-wide buffer zone may be included around the sensitive artifacts and INL CRM Office staff and Shoshone-Bannock tribal representative may monitor ground disturbing activities to ensure that no sensitive materials are inadvertently exposed. If avoidance is not possible, additional archaeological investigations, including test excavation, in advance of ground disturbance to catalog and preserve the important information present before it is damaged must be considered and plans for this work must be developed in consultation with the Shoshone-Bannock Tribes as well as the Idaho State Historic Preservation Office.

Avoidance and protection measures as described above may make the sensitive archaeological materials more visible on the landscape and thus subject to possible indirect impacts. To avoid any adverse indirect impacts from this increased visibility, training may need to be provided for individuals who work in or around developments that are situated in proximity to the sensitive area to increase awareness of the archaeological and tribal sensitivities in the area as well as legal obligations to protect cultural resources during INL activities.

\subsection{Recommendations for Additional Investigations or Protective Measures}

Once project plans are finalized, specific plans for protection of sensitive archaeological materials must be developed in cooperation with the Shoshone-Bannock Tribes. 


\section{REPOSITORY}

Upon completion of the project, all documentation (i.e. site recording forms, monitoring forms reports, field notes, etc.) will be curated at the Southeastern Idaho Regional Archaeological Center located in the Idaho Museum of Natural History on the Idaho State University campus in Pocatello, Idaho. Comprehensive permanent archives of all documentation are also maintained at the INL CRM Office in Idaho Falls, ID. In the interim between field collection and permanent curation, all materials are kept in secure temporary storage at the INL CRM Office in Idaho Falls, Idaho. 


\section{REFERENCES}

Arrowrock Group Inc., 1997, The Idaho National Engineering and Environmental Laboratory: A Historical Context and Assessment, Narrative and Inventory, INEEL/EXT-97-01021, September 1997.

DOE-ID, 1997, Idaho National Engineering Laboratory Comprehensive Facility and Land Use Plan, DOE/ID-10514, December 1997.

DOE-ID, 2007, Agreement-in-Principle (between the Shoshone-Bannock Tribes and the U.S. Department of Energy), December 2007.

DOE-ID, 2009, Idaho National Laboratory Cultural Resource Management Plan, DOE/ID-10997, Rev 3, February 2009.

Holmer, R. N., S. R. Plager, Brenda R. Pace, and T. Grieve, 2002, "A GIS Predictive Model of Archaeological Sites in Eastern Idaho," $28^{\text {th }}$ Great Basin Anthropological Conference, Elko, NV, October 2002.

Idaho State Historic Preservation Office, 1995, "Idaho Archaeological and Historical Survey Manual: Guidelines for Identifying and Evaluating Cultural Properties," Historic Preservation Series No. 8, Boise, ID.

Irving, J. S., editor, 1993, Environmental Resource Document for the Idaho National Engineering Laboratory, EGG-WMO-10279, July 1993.

Idaho State Historic Preservation Office, 1995, Idaho Archaeological and Historical Survey Manual: Guidelines for Identifying and Evaluating Cultural Properties" Historic Preservation Series No. 8, Boise, ID.

Ringe, B. L. and R. N. Holmer, 1988, “Archaeological Investigations on the Idaho National Engineering Laboratory: The Argonne National Laboratory-West Administrative Boundary," Swanson/Crabtree Anthropological Research Laboratory Reports of Investigations: 88-9.

Ringe, B. L., 1995, Locational Analysis and Preliminary Predictive Model for Prehistoric Cultural Resources on the Idaho National Engineering Laboratory, MA thesis, Department of Anthropology, Idaho State University, Pocatello, ID. 


\section{Appendix A}

Key Information 


\section{Appendix A Key Information}

A. Project name: Materials and Fuels Complex Wastewater System Upgrade

B. Project number: INL CRM Office BEA-2010-16

C. Agency name: Battelle Energy Alliance INL CRM Office for the Department of Energy Idaho Operations Office

D. Report author: Brenda R. Pace

E. Principal Investigator: Brenda R. Pace

F. Report date: May 2010

G. Counties: Bingham County

H. Legal locations and Project/Survey Acreage:

\begin{tabular}{|l|c|c|}
\hline \multicolumn{1}{|c|}{ LEGAL LOCATION } & $\begin{array}{c}\text { AREA OF POTENTIAL } \\
\text { EFFECT }\end{array}$ & $\begin{array}{c}\text { ARCHAEOLOGICAL } \\
\text { SURVEY COVERAGE }\end{array}$ \\
\hline $\begin{array}{l}\text { Southern } 1 / 2 \text { Section } 12 \text { and } \\
\text { northern } 1 / 4 \text { Section } 13, \mathrm{~T} 3 \mathrm{~N}, \\
\text { R32E }\end{array}$ & 80 acres & 80 acres \\
\hline
\end{tabular}


Appendix B

Certification of Results 


\section{Appendix B \\ Certification of Results}

CERTIFICATION OF RESULTS:

I certify that this investigation was conducted and documented according to Secretary of Interior's Standards and Guidelines and that this report is complete and accurate to the best of my knowledge.

(original signed by Brenda R. Pace)

Signature of Principal Investigator

Date 


\section{Appendix C \\ Project Maps}




\section{Appendix C Project Maps}

Appendix $\mathrm{C}$ contains project maps that show the specific locations of cultural resources. However, only those resources located in the area of potential effects for the MFC wastewater system upgrade are shown.

The cultural resource locational information presented in these maps is distributed for Official Use Only and may have been removed from some versions of the document. It is exempted from the Freedom of Information Act under Section 9 of the Archaeological Resources Protection Act of 1979 (as amended) and under Section 304 of the National Historic Preservation Act of 1966 (as amended). Distribution of any cultural resource locational information from this document and particularly from this Appendix must be approved in advance by contacting the INL CRM Office, P.O. Box 1625-2105, Idaho Falls, ID 83415, telephone: (208) 526-0916. The following maps are included here:

- Map 1: Archaeological survey boundary and area of potential effects

- Map 2: Area of potential effects with archaeological resource locations (Official Use Only)

- Map 3: Planimetric map of site 10BM247 (Official Use Only) 


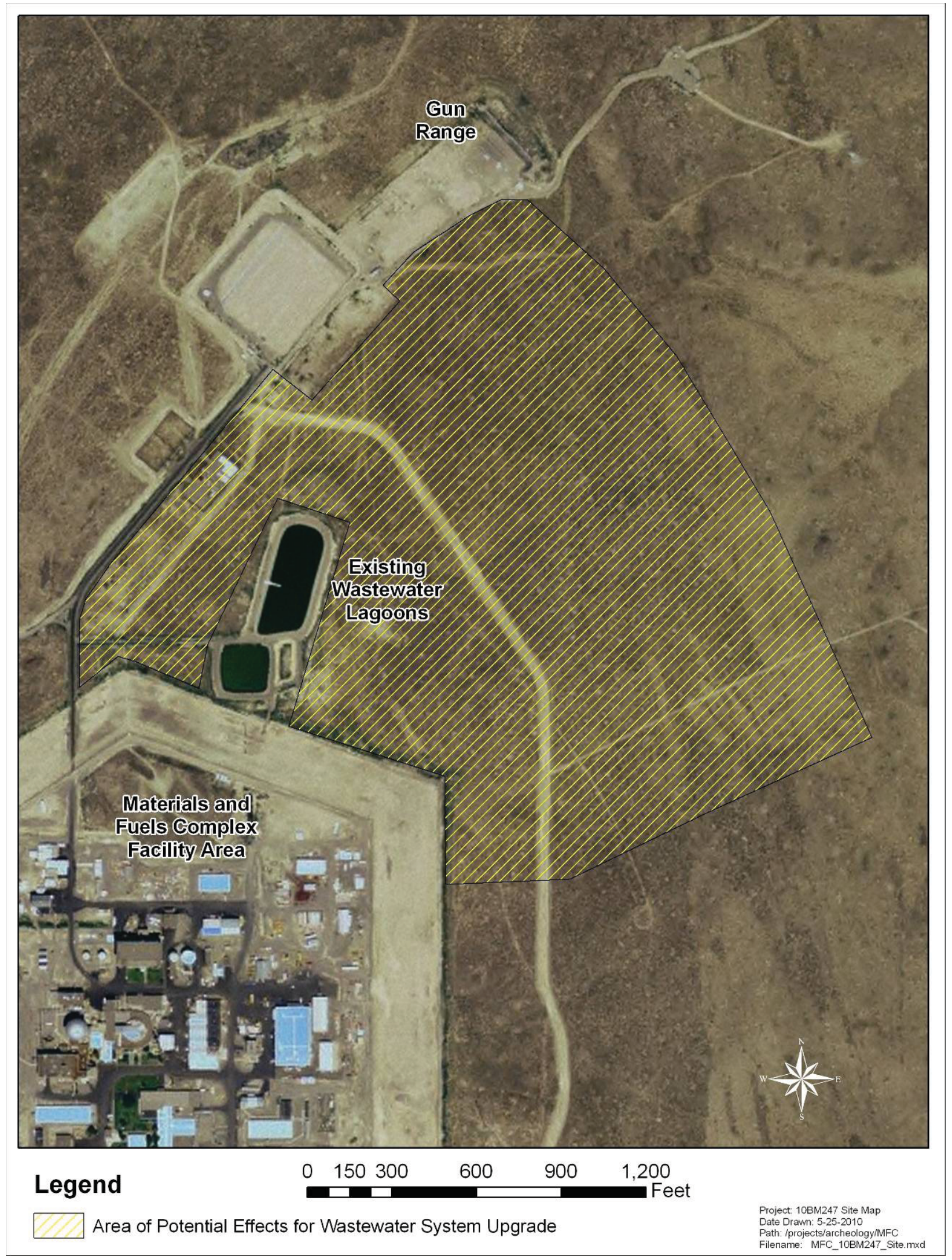

Map 1. Archaeological survey boundary and area of potential effects 
Figure Removed (Official Use Only)

Map 2. Area of potential effects with archaeological resource locations (Official Use Only). 
Figure Removed (Official Use Only)

Map 4. Planimetric map of site 10BM247 (Official Use Only). 
Appendix D

\section{Site Recording and Monitoring Forms}




\section{Appendix D Site Recording and Monitoring Forms}

The cultural resource locational information presented in these forms is distributed for Official Use Only and may have been removed from some versions of the document. It is exempted from the Freedom of Information Act under Section 9 of the Archaeological Resources Protection Act of 1979 (as amended) and under Section 304 of the National Historic Preservation Act of 1966 (as amended). Distribution of any cultural resource locational information from this document and particularly from this Appendix must be approved in advance by contacting the INL CRM Office, P.O. Box 1625-2105, Idaho Falls, ID 83415, telephone: (208) 526-0916.

The following forms are included here:

- Isolated Find Record for BEA-2010-16-01

- Monitoring Form for archaeological sites 10BM247 
Form Removed (Official Use Only) 
Form Removed (Official Use Only) 
